\title{
Are women graduates jacquelines-of-all-trades? Challenging Lazear's view on entrepreneurship
}

\author{
Silke Tegtmeier • Agnieszka Kurczewska • \\ Jantje Halberstadt
}

Accepted: 1 March 2016/Published online: 29 March 2016

(C) The Author(s) 2016. This article is published with open access at Springerlink.com

\begin{abstract}
This study challenges the basic reasoning behind Lazear's theory on entrepreneurship (2005). Based on the key motive of maximizing one's lifetime income, Lazear posits that individuals with a balanced set of skills should have a higher probability of being self-employed. His "Jack-of-all-trades" hypothesis presumes that entrepreneurs need sufficient knowledge in a variety of areas to succeed, while paid employees benefit from being specialists in a certain area demanded by the labor market. Because most women-led businesses are neither based on the motive of making money nor are they growth oriented, we argue that maximizing their lifetime income is not the main motivation of many women to start a business. However, we argue that Lazear's theory can be extended to motivations that are mostly stated for women entrepreneurs as well. We apply it to a specific
\end{abstract}

S. Tegtmeier $(\square)$

SDU Innovation and Design Engineering, Mads Clausen Institute, University of Southern Denmark, Alsion 2, 6400 Sønderborg, Denmark

e-mail: tegtmeier@mci.sdu.dk

A. Kurczewska

Faculty of Economics and Sociology, University of Lodz, Lodz, Poland

e-mail: agnieszka.kurczewska@uni.lodz.pl

J. Halberstadt

Faculty of Sustainability, Leuphana University of

Lüneburg, Lüneburg, Germany

e-mail: halberstadt@uni.leuphana.de representative sample of 1384 women graduates in Germany and test our hypothesis with logit regression. A dichotomized measure indicating whether a women graduate was self-employed $(n=706)$ or not ( $n=678$ ) served as the dependent variable. Our results widely confirm Lazear's assumption for women graduates who run relatively small businesses in terms of sales and employment: professional training, balanced industry experience, and balanced entrepreneurship-based self-efficacy increase the probability of being self-employed. Solo self-employed tend to have balanced industry experience more often than those being in a team or having employees. Lazear's theory has male as the norm, and as such, does not readily apply to the case of women-but could and should be extended to women's specifics.

Keywords Jack-of-all-trades theory · Lazear . Entrepreneurship · Self-employment · Women graduates · Entrepreneurship-based self-efficacy · Lifetime income $\cdot$ Motives

JEL Classifications $\quad \mathrm{C} 12 \cdot \mathrm{J} 24 \cdot \mathrm{J} 44 \cdot \mathrm{J} 62$. L26 $\cdot$ M13 $\cdot$ M53

\section{Introduction}

There is no entrepreneurship without entrepreneurial knowledge and skills (Lofstrom 2013). An entrepreneur creates and absorbs knowledge and uses his or her 
intellectual skills to apply it in business. Knowledge and skills can translate into entrepreneurial ideas, innovations, improvements, new practices, or applications, leading to new business ventures. However, entrepreneurship research has thus far produced insufficient evidence as to whether a particular set of knowledge and skills is needed to successfully exploit business opportunities (Galunic and Rodan 1998; Simoes et al. 2015). One important focus concerns the need for expert knowledge versus the need for general and balanced knowledge. That is, should an entrepreneur possess general knowledge and a balanced set of skills or be an expert with a narrow specialization and deep knowledge in a particular field? Edward Lazear made a decisive contribution in this field through his theory of occupational choice (Lazear 2002, 2005). Lazear argues that individuals with a balanced and diversified set of skills, gathered from various fields, are more likely to be self-employed than those who do not possess such a balanced skill set. In contrast, paid employees benefit from being specialists in a certain area demanded by the labor market. Lazear's occupational choice theory quickly became one of the most crucial theories in explaining why people choose entrepreneurship, not least because of its persuasive internal logic (Hsieh et al. forthcoming).

This paper starts with a careful examination of the assumptions of Lazear's theory. Lazear argues that individuals seek to maximize their lifetime income in their job or career choices. He proposes that individuals with a balanced set of skills can maximize their lifetime income by choosing entrepreneurship instead of employment, while experts maximize their lifetime earnings by opting for employment. Although income maximization is an important driver for professional choices, there are many other reasons for choosing a job (Carter et al. 2003; Douglas and Shepherd 2002). Among women, maximizing lifetime income-as assumed by Lazear-is not among the central motivating factors to become an entrepreneur. Women-led businesses are often not growth oriented (Morris et al. 2006; Sternberg et al. 2004; Terjesen et al. 2015) and less focused on making money compared to menowned businesses (Borooah et al. 1997; Clain 2000; Georgellis and Wall 2005).

At first glance, it appears that Lazear's theory may not hold true for women; however, this paper builds on occupational choice theory to articulate several arguments for the jacqueline-of-all-trades hypothesis based on women-specific motivations. These arguments relate to women's drive for self-fulfillment, commitment to family responsibilities, or desire to make a social impact. Following these arguments, we assume that Lazear's hypothesis holds true for women-albeit with different assumptions.

In the present study, we used a sample of graduate women entrepreneurs who run relatively small businesses in terms of sales and employment. Entrepreneurship research suggests that individuals with graduate degrees show great potential for entrepreneurship based on their high levels of education (Pinkwart 2000; Terjesen and Lloyd 2015; Ucbasaran et al. 2008). Accordingly, we formulated the following research question: Are graduate women more likely to be self-employed if they have more balanced and less specialized knowledge?

This paper contributes to the existing literature in two ways. First, it explores the origins of Lazear's theory and challenges its assumptions regarding the motivation for career choices. In doing so, the study broadens the scope of Lazear's theory to include motivating factors beyond merely economic ones. We highlight that Lazear's theory can be extended to incorporate some relevant points that have not been considered so far. These include Ahl's (2006) logic that current theories have male as the norm; as such, they do not always readily apply to women but could, and should, be extended to women.

Second, our investigation operationalizes the balanced set of skills. Prior research has mainly measured balanced skills and knowledge by the number of prior job roles (Lazear 2005; Silva 2007). Our paper assesses various aspects of education and experience that are particularly relevant for graduates, including professional training in addition to tertiary education, balanced management experience, and balanced industry experience. In addition to factors that reflect an actual set of skills, we include-as proxy measurements-individually perceived skills using balanced entrepreneurship-based self-efficacy in different entrepreneurship-based tasks.

We first present arguments to extend Lazear's theory and discuss its implications for our hypothesis. The subsequent sections describe the methodology and data, and then present our findings. The paper concludes with a discussion of results and their implications for practice and research, particularly for entrepreneurship education. 


\section{Theoretical background}

\subsection{The jack-of-all-trades approach}

In the field of entrepreneurship, there is a discussion as to whether entrepreneurs need more expert knowledge versus more general and balanced knowledge. Supporters of the former view stress that a balanced and diverse set of skills creates a unique combination that is difficult to imitate (Lippman and Rumelt 1982); such a profile hones a company's competitive advantage and generates more solutions to the problems the company may encounter. The richness of skills is useful when changes force a company to adapt and find creative solutions (Galunic and Rodan 1998). In contrast, supporters of the expert knowledge perspective highlight that to understand entrepreneurship, it is necessary to learn more about how an individual becomes an expert entrepreneur (Krueger 2007). They focus more on the potential of knowledge structures and schemes of expert entrepreneurs (Baron 2006; Baron and Henry 2010). These scholars also believe that specialist knowledge equips individuals with a unique set of tools that enables them to create the best solutions to problems and generally helps them connect different areas of knowledge and inspiration when new ideas are needed.

Lazear's (2005) jack-of-all-trades hypothesis assumes that entrepreneurs must be competent in many fields; they must possess balanced skills and have at least basic knowledge in numerous areas. Paid employees, in contrast, gain more from being specialists in a particular area that is desired by the labor market. As Lazear argues,

The idea $[\ldots]$ is that entrepreneurs differ from specialists in that entrepreneurs have a comparative disadvantage in a single skill but have more balanced talents that span a number of different skills. Specialists can work for others who have the talent to spot and combine a variety of skills, but an entrepreneur must possess that talent. Although entrepreneurs can hire others, the entrepreneur must be sufficiently well versed in a variety of fields to judge the quality of applicants (2005, p. 650).

Thus, the theory posits that entrepreneurs are jacks-ofall-trades. Their basic knowledge about everything is often complementary to their employees' expert knowledge. In practice, this means that individuals with varied educational and professional backgrounds who play diverse roles in their careers are more likely to become entrepreneurs than individuals who follow one straight path.

Lazear (2005) tested and confirmed his hypothesis with a sample of Stanford MBA alumni. Individuals who have more varied careers (i.e. who have performed more roles) are more likely to become entrepreneurs. Lazear provides two interpretations of his results, both supporting the jack-of-all-trades perspective. The first interpretation suggests that the correlation between the number of roles and entrepreneurship results from endowed differences in skills across populations, as individuals with more general skills are able to perform more roles. The second interpretation states that this correlation is a result of conscious investment: Individuals aspiring to become entrepreneurs try many roles to gain knowledge and skills necessary to start a business venture.

Lazear's theory has also been confirmed in studies by Åstebro and Thompson (2011), Backes-Gellner and Moog (2013), Hartog et al. (2010), Stuetzer et al. (2013), and Wagner (2003, 2006). It is also somewhat supported by Lechmann and Schnabel (2014), who promote the view of a multi-skilled entrepreneur but do not support Lazear's idea that human capital investment patterns differ between entrepreneurs and paid employees. Oberschachtsiek's (2012) research on balanced skill sets and self-employment duration reveals that combined practical experience and adequate skills are decisive for longevity in self-employment. Although the evidence from most research confirms Lazear's theory, the robustness of former results has also been called into question. For example, Silva (2007) does not find any support for Lazear's theory, indicating a need for new approaches. Table 1 summarizes the foci and key findings of prior studies.

A recent study shows that individuals are motivated to invest in balanced skill profiles due to their risk aversion, which consequently makes them more likely to become entrepreneurs (Hsieh et al. forthcoming). This study argues that risk-averse people fear losing flexibility when specializing in only one area of human capital. Following this argument, risk-averse individuals tend to become entrepreneurs, a finding that unveils mixed evidence in the extant research on risk aversion and entrepreneurship. 
Table 1 Prior work using Lazear's theory to predict self-employment

\begin{tabular}{|c|c|c|c|}
\hline Author (year) & Sample & $\begin{array}{l}\text { Sample } \\
\text { size }\end{array}$ & Key findings \\
\hline $\begin{array}{l}\text { Lazear }(2002, \\
\text { 2005) }\end{array}$ & $\begin{array}{l}\text { Stanford MBA alumni, diverse industries; } 83 \% \\
\text { are male }\end{array}$ & 20,920 & $\begin{array}{l}\text { Individuals with varied work and education } \\
\text { backgrounds are more likely to start their own } \\
\text { business than are individuals who focused on a } \\
\text { single role and subject at work and at school }\end{array}$ \\
\hline Wagner (2003) & $\begin{array}{l}\text { SOEP; representative sample of the German } \\
\text { working population; } 67 \% \text { are male }\end{array}$ & 33,633 & $\begin{array}{l}\text { Individuals with more different kinds of } \\
\text { professional training and changes in profession } \\
\text { are more likely to be self-employed }\end{array}$ \\
\hline Wagner (2006) & $\begin{array}{l}\text { Regional entrepreneurship monitor, Germany; } \\
\text { nascent entrepreneurs and individuals who } \\
\text { intend to continue working as paid employees; } \\
79 \% \text { are male }\end{array}$ & 12,000 & $\begin{array}{l}\text { Individuals with more fields of experience and } \\
\text { professional degrees are more likely to be } \\
\text { nascent entrepreneurs }\end{array}$ \\
\hline Silva (2007) & $\begin{array}{l}\text { ILFI Survey of Italian Families; } 93 \% \text { of the } \\
\text { entrepreneurs are male, } 89 \% \text { of the employed } \\
\text { workers are male }\end{array}$ & 5173 & $\begin{array}{l}\text { Individuals with expertise across various subjects } \\
\text { are not more likely to become entrepreneurs }\end{array}$ \\
\hline $\begin{array}{l}\text { Hartog et al. } \\
\text { (2010) }\end{array}$ & $\begin{array}{l}\text { U.S. National Longitudinal Survey of Youth } \\
\text { 1979-2000; } 63 \% \text { of the entrepreneurs are } \\
\text { male, } 51 \% \text { of the non-entrepreneurs are male }\end{array}$ & 4472 & $\begin{array}{l}\text { Individuals with a more balanced portfolio of } \\
\text { abilities such as cognitive ability and social } \\
\text { ability will earn more than an entrepreneur. } \\
\text { This balanced portfolio does not increase } \\
\text { employees' earnings }\end{array}$ \\
\hline $\begin{array}{l}\text { Astebro and } \\
\text { Thompson } \\
\text { (2011) }\end{array}$ & $\begin{array}{l}\text { Canadian Innovation Centre; list of independent } \\
\text { inventors and individuals from the general } \\
\text { population in Canada; } 91 \% \text { are male }\end{array}$ & 1029 & $\begin{array}{l}\text { Inventor-entrepreneurs typically have more } \\
\text { varied labor market experiences which are } \\
\text { associated with lower household income. } \\
\text { Entrepreneurs have more varied labor market } \\
\text { experience }\end{array}$ \\
\hline $\begin{array}{l}\text { Oberschachtsiek } \\
\text { (2012) }\end{array}$ & $\begin{array}{l}\text { Individuals who applied for bridging allowances } \\
\text { in the northern region of the German federal } \\
\text { state of Lower Saxony; } 70 \% \text { are male }\end{array}$ & 645 & $\begin{array}{l}\text { Individuals are more likely to stay in self- } \\
\text { employment if they possess a combination of } \\
\text { practical experience and adequate skills. Broad } \\
\text { experience combined with business/sales } \\
\text { competence is particularly associated with } \\
\text { persistence in self-employment }\end{array}$ \\
\hline $\begin{array}{l}\text { Backes-Gellner } \\
\text { and Moog } \\
(2013)\end{array}$ & $\begin{array}{l}\text { Cologne Founder Study of German university } \\
\text { students from all major study fields; } 59 \% \text { are } \\
\text { male }\end{array}$ & 2073 & $\begin{array}{l}\text { Individuals with a more balanced and combined } \\
\text { portfolio of human capital, social capital, and } \\
\text { experiences are more likely to have considered } \\
\text { becoming an entrepreneur }\end{array}$ \\
\hline $\begin{array}{l}\text { Stuetzer et al. } \\
\text { (2013) }\end{array}$ & $\begin{array}{l}\text { Thuringian Founder Study; two data sets on } \\
\text { innovative new firms; } 92 \text { and } 89 \% \text { are male }\end{array}$ & $521+92$ & $\begin{array}{l}\text { Entrepreneurs with a varied set of work } \\
\text { experience have higher entrepreneurial skills } \\
\text { which are relevant for starting and growing a } \\
\text { firm }\end{array}$ \\
\hline $\begin{array}{l}\text { Lechmann and } \\
\text { Schnabel } \\
(2014)\end{array}$ & $\begin{array}{l}\text { BIBB/BauA Employment Survey of the Working } \\
\text { Population on Qualification and Working } \\
\text { Conditions in Germany; } 65 \% \text { of entrepreneurs } \\
\text { are male, } 50 \% \text { of non-entrepreneurs are male }\end{array}$ & 18,990 & $\begin{array}{l}\text { Self-employed hardly differ from individuals in } \\
\text { paid employment in human capital investment } \\
\text { patterns }\end{array}$ \\
\hline
\end{tabular}

\subsection{A new approach to Lazear's theory}

We approach Lazear's theory by questioning its assumptions. Lazear posits that individuals with a balanced set of skills and knowledge can maximize their lifetime income by being self-employed, while specialists can maximize their income by working as paid employees. This reasoning does not consider different motivations for entrepreneurial behavior. Studies show alternative motivations to maximization of lifetime income particularly among women entrepreneurs as their companies are often less growth 
oriented (Morris et al. 2006; Sternberg et al. 2004) and less focused on profits (Borooah et al. 1997; Clain 2000; DeMartino and Barbato 2003; Fischer et al. 1993; Georgellis and Wall 2005; Marlow 1997; Scott 1986; Wilson et al. 2004). Moreover, the majority of women-owned businesses have lower revenues and fewer employees and are situated in lower-profit industries than men-owned ones (Bird 1989; Morris et al. 2006). There are also significant differences in how women view themselves, their families, their ventures, and the broader environment (Morris et al. 2006). Women's motives include self-fulfillment, social impact, and helping others (Brush 1992), along with fulfilling family responsibilities (Morris et al. 2006; Stevenson 1986).

Thus, on the one hand, one could argue that Lazear's hypothesis is not applicable to women because these diverse factors are missing in Lazear's underlying assumption. On the other hand, the jack-ofall-trades hypothesis could be seen to hold especially true for women insofar as women add an even broader set of abilities to Lazear's balanced set of skills. In this sense, a balanced set of skills may still have a positive influence on entrepreneurial activity even though women have diverse motives in becoming entrepreneur. Let us look at these alternative motivations in detail.

First, women often indicate self-fulfillment as a key motivation for their career choice (Brush 1992). It can be assumed that individuals with a balanced set of skills also maximize their personal self-fulfillment better as an entrepreneur than as an employee. Their balanced set of skills may be due to dissatisfaction with former jobs (Kirkwood 2009) and the need for greater variety in their work. This in turn leads to more self-fulfillment in entrepreneurial activity, which requires engagement in various fields. In this line of thought, women with a more varied set of skills tend to be more satisfied as entrepreneurs, whereas specialists find greater self-fulfillment by pursuing their special skills.

A second women-specific motivation for job decisions is maximizing social impact (Brush 1992). If we assume that helping others is a principal motive for women, then those with a balanced set of skills can maximize their social impact through a socially conscious business, while the specialists can maximize their social impact by being employed, for example, as a nurse.
Fulfilling family duties is a third strong motive for women's career choices (Morris et al. 2006; Stevenson 1986). Even if choices might be more necessity driven in this case, it can be argued that balanced skills lead to a higher probability of self-employment. For a specialist, it will be easier to find a good, secure job that can easily become part-time since it covers narrowly defined tasks in comparison with selfemployed work. Individuals with a balanced set of skills do not easily fit into such a specialized area. They might instead maximize their fulfillment of family duties by using their flexibility, which they have learned by building up a variety of skills. In a self-employed position, people have greater freedom to choose and, as a consequence, to reduce working time and intensity, but they need to be an "allrounder" to still successfully manage the business as well as family tasks. This applies to jacquelines-of-alltrades.

At this point we might ask, does Lazear's hypothesis hold true for women even though they often do not prioritize maximizing lifetime income as a motive for professional choices? Following the arguments above, we assume that Lazear's hypothesis does hold true for women-albeit with different assumptions. Thus, in accordance with Lazear (2005), our main hypothesis is:

H1 The probability of women being entrepreneurs increases with a balanced set of skills.

The focus on women not only broadens Lazear's view by including women-specific motives but also is an answer to the suggestion of many authors to focus on women specifically instead of considering them as a homogeneous group and as an opposite of men (Ahl 2006). In our case, this is of particular relevance as women play an increasingly important role in entrepreneurship throughout the world (Acs et al. 2011; European Commission 2016; Sternberg et al. 2013; Terjesen and Lloyd 2015; Xavier et al. 2013). We have thus related Lazear's theory to this group of entrepreneurs. We have followed Ahl's (2006) argument that although these current theories are built around male archetypes, they can be extended to account for women entrepreneurs as well. In contrast to former work that uses mixed samples with just a minor percentage of women, we focus our approach purely on women. As suggested in Ahl's work, we seek to capture a richer picture of women 
entrepreneurship and to use women non-entrepreneurs as a control group, instead of consolidating the masculine interpretation of entrepreneurship (Galloway et al. 2015; Gupta et al. 2008, 2009; Holmquist and Carter 2009; Jennings and Brush 2013).

\section{Methodology}

\subsection{The sample}

To check whether Lazear's theory remains valid without the motivation of maximizing lifetime income, we examined a specific sample of graduate women entrepreneurs who run relatively small businesses in terms of sales and employment. Our study tests Lazear's theory on a representative sample of 1384 women graduates in Germany. Despite the theory was tested and confirmed in the German context (see Table 1), prior studies have not focused on entrepreneurial activity by women graduates. The lack of prior studies may be because graduate women entrepreneurs are not adequately represented in largescale data sets of the German population or in labor statistics, e.g., German Socio-Economic Panel (Heimann-Roppelt and Tegtmeier in press), or the German Microcensus. In consequence, Lazear's theory has never been tested specifically on women with graduate degrees, who exhibit great potential for entrepreneurship based on their high levels of education. Although Germany has recently been ranked number 14 of 77 countries in a recent Female Entrepreneurship Index (Terjesen and Lloyd 2015), women still start businesses less often than men (e.g., Wagner 2007; Xavier et al. 2013).

We focus only on graduates because this group is homogeneous in terms of education levels (Tegtmeier and Mitra 2015a, b). Accordingly, differences in human and social capital between individuals mainly relate to the balance of skills rather than the level of skills (Hsieh et al. forthcoming). Instead of investigating the intentions of would-be self-employed individuals, we compare individuals who are already self-employed with those who are not. In doing so, we expect to reveal more direct insights into the impetuses of self-employment.

TNS Emnid, a leading market research institute, collected the data in order to ensure a Germany-wide representative study (Tegtmeier and Kurczewska in press). TNS Emnid screened through random digit dialing using the German ADM sampling system, the Hoppenstedt company sample, and the German yellow pages (excluding companies that are typically led by non-graduates, e.g., hairdressers). In the screening calls, those contacted were asked if they were currently a self-employed woman graduate (820) or a non-self-employed woman graduate (832). Respondents who fell into either category were then interviewed by telephone.

We created a subsample of participants who were older than 20 and younger than 66 (65 was formerly the mandatory retirement age for paid employees) and of entrepreneurs who were running their first business at the time of investigation. This resulted in a subsample of 706 graduate women entrepreneurs and 678 women graduates who were not entrepreneurs. The individual and venture age cut-offs are typical for entrepreneurship research (Reynolds et al. 2005; Davidsson 2005).

As the dependent variable, we used an indicator taking the value 1 if the individual was self-employed and 0 if she was not self-employed. In line with Parker (2009), we consider self-employed (e.g., Bates 1995; Blanchflower 2000, 2004) to constitute entrepreneurs (for a critical analysis about the meaning of entrepreneurship see Audretsch et al. 2015) and consequently operationalize entrepreneurship as selfemployment (see also Åstebro et al. 2012; Folta et al. 2010; Hsieh et al. forthcoming). Åstebro and Thompson (2011) show in their investigation of Lazear's theory that there was no substantial difference when entrepreneurship was proxied by self-employment, business creation, or business ownership.

To capture the breadth of experience of the participants, we measured a set of variables as proxies for the diversity of skills and knowledge related to selfemployment. To operationalize a balanced set of skills, we assessed aspects of education and experience particularly relevant for women graduates: Additional professional training, balanced industry experience, and balanced management experience. In addition to these factors reflecting a "hard" set of skills, we included individually perceived skills using balanced entrepreneurship-based self-efficacy (ESE). The ESE construct is widely adopted in entrepreneurship research, particularly in relation to entrepreneurial intentions (see, e.g., Piperopoulos and Dimov 2015). ESE traces back to social cognitive theory, which 
explains psychosocial functioning as reciprocal causation of behavior, cognition, and environmental events (Wood and Bandura 1989). Bandura (1978) defines selfefficacy as perceiving a successful execution of behavior for a given outcome. ESE stands for an individual's perception that she is able to successfully accomplish the tasks and roles of an entrepreneur (Chen et al. 1998).

\subsection{Independent variables}

Following Lazear (2005), we focused on how knowledge in a variety of areas impacts the probability of becoming self-employed. We applied the following four variables.

\subsubsection{Additional professional training}

The German Chamber of Industry and Commerce offers professional training as an alternative to an academic education. The 2- to 3-year training is generally a combination of a traineeship at a company and schooling, after which students often enter university. Within the company, the trainee moves from unit to unit, learning about the organizational structure as well as the diverse functions of each area. Completion of such a sophisticated training program was included as an indicator based on the assumption that this training yields a broader set of skills than a regular course of study alone. Indeed, this form of training gives a balance of both scientific knowledge from a university and practical know-how from intensive on-the-job training. This measure is in line with other work on Lazear's theory that was conducted with German data and included professional training programs (Wagner 2003, 2006).

\subsubsection{Balanced industry experience}

We included this measure as it reflects the variety of skills gained through practical experience. Participants indicated how many industries (in German: "Branchen") they had worked in over their careers. Those who had worked in more than three industries were flagged as having balanced industry experience. In line with prior studies (see Wagner 2003, which includes changes of profession), we assumed that individuals who possess experience from diverse industries have a more balanced set of skills than those who have worked in fewer industries.

\subsubsection{Balanced management experience}

A balanced set of skills is also indicated through participants' involvement in diverse fields of management activities before launching a business, including marketing/sales, accounting/controlling, financial management, human resource management, purchasing/supply management, and organization of work processes. The number of applicable fields is a measure of each respondent's diversity of management experience.

\subsubsection{Well-balanced ESE}

Our measure of well-balanced ESE (Tegtmeier and Mitra 2015a, b) is based on a validated multidimensional scale (McGee et al. 2009). This measure is superior to its predecessors as it captures the multidimensionality as well as the task and role relevance of the construct. The women are asked to indicate on 5 -point Likert scales ( $1=$ very little, $5=$ very much) how much confidence they have in their ability to engage in 19 entrepreneurship-related tasks, such as identifying the need for a new product or service or reading and interpreting financial statements. By factor analysis, McGee et al. (2009) have shown that this overall scale can be divided into five sub-scales: searching (Cronbach's $\alpha=.84$ ), planning (Cronbach's $\alpha=.84$ ), marshaling (Cronbach's $\alpha=.80$ ), implementing-people (Cronbach's $\alpha=.91$ ), and implementing-financial (Cronbach's $\alpha=.84$ ). Searching includes tasks such as brainstorming (coming up with) a new idea for a product or service, identifying the need for a new product or service, and designing a product or service that will satisfy customer needs and wants. Planning includes estimating customer demand for a new product or service, determining a competitive price for a new product or service, estimating the amount of start-up funds and working capital necessary to start a business, and designing an effective marketing/advertising campaign for a new product or service. Marshaling includes tasks such as getting others to identify with and believe in the vision and plans for a new business, networking (i.e., making contact with and exchanging information with others), and explaining a business idea clearly and concisely in everyday terms, both verbally and in writing. Implementingpeople includes tasks such as recruiting and hiring employees; training and supervising employees; 
delegating tasks and responsibilities; dealing effectively with day-to-day problems and crises; and inspiring, encouraging, and motivating employees. Finally, implementing-financial covers tasks such as organizing and maintaining financial records, managing financial assets, and reading and interpreting financial statements (McGee et al. 2009). In our study, we calculated the mean for each sub-scale and took the standard deviation of the sub-constructs as a measure for the balance of ESE. For example, a woman may indicate a high level of perceived self-efficacy in searching and planning, but a low level in marshaling, implementing-people, and implementing-financial. This would be an unbalanced ESE with regard to the five areas of entrepreneurial roles and tasks. An equal level of ESE in all five areas would indicate a balanced ESE.

\subsection{Controls}

We controlled for participant age, the existence of children and a life partner, whether the participant's parents had ever been self-employed, whether the participant's former course of study was mainly related to economics/management, and whether she had completed a university degree (Davidsson 2005; Reynolds et al. 2005; Shaver et al. 2001). The German higher education system distinguishes between research universities, universities of applied sciences, and academies that award at least bachelor's degrees. Accordingly, we controlled for whether the women entrepreneur graduated from a research university or from one of the other institutions. We also controlled for work experience and for whether the participant was ever unemployed in the sense of seeking work, which is mostly researched as a "push" factor into self-employment (see, e.g., Biehl et al. 2014; Svaleryd 2015). Work experience is operationalized as the number of years the participant has been employed.

\subsection{Descriptive statistics}

Table 2 presents the means, standard deviations, minima, and maxima of these variables for both groups (graduate women entrepreneurs and graduate women who were non-entrepreneurs) as well as the entire sample.

Self-employed graduate women were on average 4.6 years older and more likely to have children. Self- employed graduate women were more often likely to have completed an additional professional training program and to possess more balanced industry experience along with a more balanced ESE. However, as compared to their non-self-employed graduate counterparts, self-employed graduate women reported less balanced management experience with regard to diverse management fields. The descriptive evidence in Table 2 indicates some hints in favor of the jack-ofall-trades hypothesis posited by Lazear.

Table 3 presents a correlation matrix for variables used in the analysis and their variance inflation factors (VIFs). The VIFs confirm that multicollinearity is not an issue here.

\section{Analysis and results}

\subsection{Primary analysis}

We tested the hypothesis using logit regression in STATA version 11.0. We estimated a model with the dichotomized measure indicating whether a women graduate is self-employed or not as the dependent variable. Logit estimates are reported in Table 4 (Model A).

The estimated Model A had a Pseudo $R^{2}$ of 0.2025 and was significant at the 0.000 level (Table 4). The probability of being self-employed increases with the participant's age $(<0.001)$, parental self-employment $(<0.01)$, additional professional training $(<0.001)$, balanced industry experience $(<0.01)$, and wellbalanced ESE $(<0.001)$. In contrast, the existence of a life partner $(<0.05)$, work experience in years $(<0.001)$, and balanced management experience $(<0.001)$ correlates with a decrease in probability. Note that unlike the existence of a life partner, the existence of children does not show any statistically significant effect.

Hence, three of four proxies to measure a balanced set of skills confirm that graduate women entrepreneurs are jacquelines-of-all-trades. The probability of self-employment increases with the existence of further professional training (preceding university studies) and with balanced industry experience. Likewise, more balanced ESE (in the areas of searching, planning, marshaling, implementing-people, and implementing-financial) correlates with higher probability of being self-employed. These results mainly 
Table 2 Means, standard deviations, minima, and maxima of modeled constructs ${ }^{\mathrm{a}}(N=1.384)$

\begin{tabular}{|c|c|c|c|c|}
\hline Variable & Mean & SD & Min & $\operatorname{Max}$ \\
\hline \multicolumn{5}{|l|}{ A. Entire sample $(n=1384)$} \\
\hline Age (years) & 46.88 & 10.59 & 21 & 65 \\
\hline Children $(1=$ yes $)$ & 0.71 & 0.46 & 0 & 1 \\
\hline Partner $(1=$ yes $)$ & 0.81 & 0.39 & 0 & 1 \\
\hline Parental role model $(1=$ yes $)$ & 0.34 & 0.47 & 0 & 1 \\
\hline Economics/management as course of study $(1=$ yes $)$ & 0.11 & 0.32 & 0 & 1 \\
\hline Research university education $(1=$ yes $)$ & 0.71 & 0.45 & 0 & 1 \\
\hline No unemployment $(1=$ yes $)$ & 0.60 & 0.49 & 0 & 1 \\
\hline Work experience (years) & 12.02 & 11.08 & 0 & 47 \\
\hline Additional professional training $(1=$ yes $)$ & 0.40 & 0.49 & 0 & 1 \\
\hline Balanced industry experience $(1:>3$ industries $)$ & 0.13 & 0.34 & 0 & 1 \\
\hline Balanced management experience (no. of fields) & 1.41 & 1.53 & 0 & 6 \\
\hline Well-balanced entrepreneurship-based self-efficacy (SD fields) & -0.66 & 0.29 & -1.71 & 0 \\
\hline \multicolumn{5}{|l|}{ B. Non-entrepreneurs $(n=678)$} \\
\hline Age (years) & 44.54 & 12.08 & 21 & 65 \\
\hline Children $(1=$ yes $)$ & 0.67 & 0.47 & 0 & 1 \\
\hline Partner $(1=$ yes $)$ & 0.81 & 0.40 & 0 & 1 \\
\hline Parental role model $(1=$ yes $)$ & 0.29 & 0.45 & 0 & 1 \\
\hline Economics/management as course of study $(1=$ yes $)$ & 0.15 & 0.36 & 0 & 1 \\
\hline Research university education ( $1=$ yes $)$ & 0.70 & 0.46 & 0 & 1 \\
\hline No unemployment $(1$ = yes $)$ & 0.63 & 0.48 & 0 & 1 \\
\hline Work experience (years) & 14.31 & 12.45 & 0 & 47 \\
\hline Additional professional training $(1=$ yes $)$ & 0.32 & 0.47 & 0 & 1 \\
\hline Balanced industry experience (1: $>3$ industries) & 0.11 & 0.31 & 0 & 1 \\
\hline Balanced management experience (no. of fields) & 1.78 & 1.58 & 0 & 6 \\
\hline Well-balanced entrepreneurship-based self-efficacy (SD fields) & -0.68 & 0.29 & -1.71 & 0 \\
\hline \multicolumn{5}{|l|}{ C. Entrepreneurs $(n=706)$} \\
\hline Age (years) & 49.14 & 8.34 & 23 & 65 \\
\hline Children $(1=$ yes $)$ & 0.74 & 0.44 & 0 & 1 \\
\hline Partner $(1=$ yes $)$ & 0.81 & 0.39 & 0 & 1 \\
\hline Parental role model $(1=$ yes $)$ & 0.39 & 0.49 & 0 & 1 \\
\hline Economics/management as course of study $(1=$ yes $)$ & 0.08 & 0.27 & 0 & 1 \\
\hline Research university education ( $1=$ yes $)$ & 0.73 & 0.45 & 0 & 1 \\
\hline No unemployment $(1$ = yes $)$ & 0.57 & 0.50 & 0 & 1 \\
\hline Work experience (years) & 9.83 & 9.06 & 0 & 45 \\
\hline Additional professional training $(1=$ yes $)$ & 0.48 & 0.50 & 0 & 1 \\
\hline Balanced industry experience (1:>3 industries) & 0.15 & 0.36 & 0 & 1 \\
\hline Balanced management experience (no. of fields) & 1.05 & 1.39 & 0 & 6 \\
\hline Well-balanced entrepreneurship-based self-efficacy (SD fields) & -0.63 & 0.29 & -1.66 & 0 \\
\hline
\end{tabular}

$S D$ standard deviation

confirm the jack-of-all-trades hypothesis. There is no support for the hypothesis concerning the expected positive effect of balanced management experience on self-employment.

\subsection{Robustness checks}

The former analysis is based on an unrestricted sample. We ran several robustness checks. First, we 


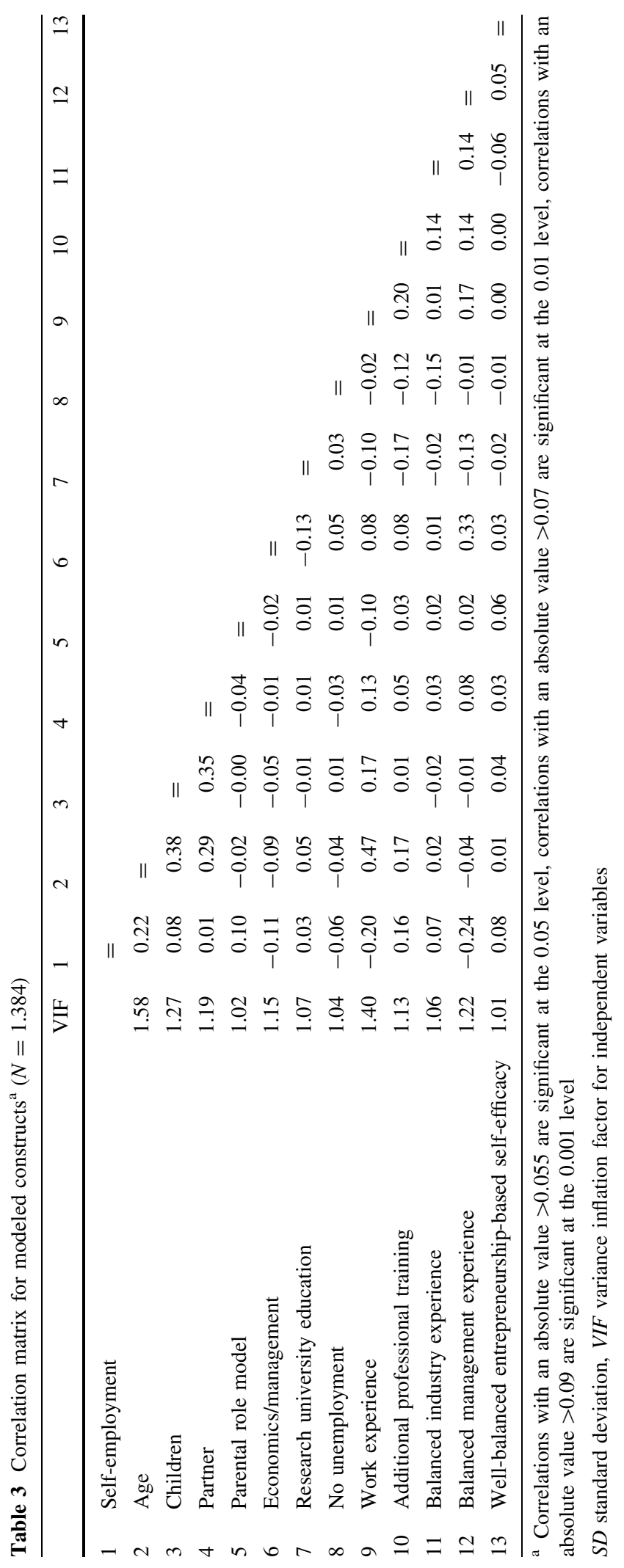


Table 4 Results of logit regression for being selfemployed $(N=1384)$
$S E$ standard errors

Significance

levels: ${ }^{+} p<0.10$,

$* p<0.05, * * p<0.01$,

$* * * p<0.001$

\begin{tabular}{lcc}
\hline & Model A & \\
\cline { 2 - 3 } & Coeff. & SE \\
\hline Age (years) & $0.084 * * *$ & 0.008 \\
Children $(1=$ yes) & 0.107 & 0.154 \\
Partner $(1=$ yes) & $-0.349 *$ & 0.174 \\
Parental role model (1 = yes) & $0.380 * *$ & 0.133 \\
Economics/management as course of study $(1=$ yes) & 0.016 & 0.213 \\
Research university education $(1=$ yes) & -0.046 & 0.142 \\
No unemployment $(1=$ yes) & -0.123 & 0.129 \\
Work experience (years) & $-0.082 * * *$ & 0.007 \\
Additional professional training $(1=$ yes) & $1.000 * * *$ & 0.139 \\
Balanced industry experience $(1:>3$ industries) & $0.539 * *$ & 0.193 \\
Balanced management experience (no. of fields) & $-0.341 * * *$ & 0.046 \\
Well-balanced entrepreneurship-based self-efficacy (SD fields) & $0.761 * * *$ & 0.217 \\
Constant & $-2.196 * * *$ & 0.000 \\
Pseudo $R^{2}$ & 0.2025 & \\
Prob $>$ chi ${ }^{2}$ & 0.000 & \\
\hline
\end{tabular}

calculated the model only for people who reported having 40 years or less of work experience. This robustness check is motivated by the frequency distribution of the answers to the question about work experience: $50 \%$ of all interviewees reported 8 years or less of work experience, $30 \%$ reported between 9 and 20 years, $19 \%$ reported between 21 and 40 years, and only about $1 \%$ reported over 40 years. Only a handful of responses reported the most years of work experience: $41(N=4), 42(N=4), 43(N=2), 44$ $(N=2), 45(N=1), 46(N=2)$, and $47(N=1)$. Given that extreme values can have a substantial impact on results (Wagner 2006), we used a restricted sample of those with 40 years or less of work experience.

The restricted sample consisted of 1368 cases $(703$ graduate women entrepreneurs and 665 women graduates who are not entrepreneurs). With a Pseudo $R^{2}$ of 0.2008 , this robustness check revealed most similar results to the primary analysis. Accordingly, the outliers do not substantially change the results.

A second robustness check eliminated CEOs from the initial sample. Participants who were non-selfemployed provided information about the level of their employment contract within their company's hierarchy. Twenty-two indicated that they were in a CEO position with substantial decision-making and managerial power. Although these participants are not entrepreneurs themselves in the sense of being business owners, their profiles correspond to some extent with entrepreneurs. The restricted sample consists of 1362 cases (706 graduate women entrepreneurs and 656 women graduates who were not entrepreneurs). Again, with a Pseudo $R^{2}$ of 0.2008 , this robustness check revealed quite similar results. Accordingly, neither the outliers in work experience nor the CEOs substantially changed the results. The outcomes of both robustness checks are not reported in a table but are available on request.

\subsection{Further analysis}

As another variation, we divided the sub-sample of women graduate entrepreneurs into two groups: solo entrepreneurs and those who were part of a team of founders. There were 376 solo entrepreneurs, who did not start their businesses with a team and did not have any employees at the time of the investigation. In contrast, 324 entrepreneurs either started their business in a team or had at least one employee. With team members or employees, entrepreneurs can compensate for missing competences more easily. Accordingly, tracing back to Lazear's jack-of-all-trades theory, we assumed that solo entrepreneurs have a higher tendency to be generalists than those with teams or employees. 
We estimated a model with the dependent variable being the dichotomized measure of whether a women graduate was a solo entrepreneur or not. Table 5 reports the logit estimates (Model B).

The estimated Model B has a Pseudo $R^{2}$ of 0.082 and is significant at the 0.000 level (Table 5). The probability of being a solo entrepreneur decreases with parental self-employment $(<0.01)$, economics/management as course of study $(<0.05)$, research university education $(<0.001)$, and never having been unemployed $(<0.01)$. In contrast, balanced industry experience $(<0.001)$ correlates with an increase in the probability of being a solo entrepreneur. Note that balanced industry experience barely correlates with participant age $(r=0.0624, p<0.10)$.

It is worth highlighting that the correlation between the age of the business and being a solo entrepreneur is only slightly negative $(r=-0.0944, p<0.05)$. Note that the existence of a life partner as well as the existence of children does not show any statistically significant effect. Descriptive statistics of this variation are not reported in a table but are available on request.

To sum up, this analysis partly confirms that solo entrepreneurs tend to be jacquelines-of-all-trades. Out of four proxies that we used to measure being a generalist, only balanced industry experience is significant and correlates with an increase in the probability of being a solo entrepreneur.

\section{Discussion}

Despite our focus on women only and Lazear's original assumptions about career motives, our results predominantly support Lazear's jack-of-all-trades theory for the sample of graduate women entrepreneurs. Thus, in comparison with other areas of research, which highlights and sometimes overestimate differences between men and women (Ahl 2006), we theoretically argue and empirically underline that women with a balanced set of skills-like men with this profile-tend to choose entrepreneurial activity more often.

The findings also offer insights into the specific skill sets that lead to a higher probability of selfemployment and suggest that women graduate entrepreneurs tend to have a more balanced set of skills derived from additional professional training than non-entrepreneurs. That special combination of a practice-oriented traineeship at a company and a theory-oriented course of study seems to be an effective education for fostering entrepreneurial intentions. It seems to be a promising approach to not force students to choose between practical or theoretical education, but rather to let them integrate both within a teaching and learning environment that relate the two spheres (Neck and Greene 2011). The call for less specialized education to foster entrepreneurship is in line with Hsieh et al. (forthcoming), who suggest a less
Table 5 Results of logit regression for being a solo entrepreneur $(N=700)$
SE standard errors

Significance

levels: ${ }^{+} p<0.10$

$* p<0.05$, ** $p<0.01$,

$* * * p<0.001$

\begin{tabular}{lcr}
\hline & Model B & \\
\cline { 2 - 3 } & Coeff. & SE \\
\hline Age (years) & -0.000 & 0.011 \\
Children $(1=$ yes) & -0.280 & 0.195 \\
Partner $(1=$ yes) & 0.157 & 0.218 \\
Parental role model $(1=$ yes) & $-0.548^{* *}$ & 0.166 \\
Economics/management as course of study $(1=$ yes) & $-0.694^{*}$ & 0.325 \\
Research university education $(1=$ yes) & $-0.831^{* * *}$ & 0.191 \\
No unemployment $(1=$ yes) & $-0.561^{* *}$ & 0.167 \\
Work experience (years) & -0.004 & 0.010 \\
Additional professional training $(1=$ yes) & 0.107 & 0.170 \\
Balanced industry experience $(1:>3$ industries) & $0.936^{* * *}$ & 0.256 \\
Balanced management experience (no. of fields) & -0.021 & 0.064 \\
Well-balanced entrepreneurship-based self-efficacy (SD fields) & -0.462 & 0.281 \\
Constant & 1.048 & 0.556 \\
Pseudo $R^{2}$ & 0.082 & \\
Prob $>$ chi ${ }^{2}$ & 0.000 & \\
\hline
\end{tabular}


specialized school curriculum. As this educational concept is mainly offered in German-speaking countries at present, we see a need for further analysis of this approach to suggest ways of spreading it to other countries.

The impact of balanced industry experience on the probability of self-employment shows that observing the business world from different perspectives and gaining experience in a variety of branches is important to cultivate entrepreneurial skills. This result shows not only that varied experience increases the probability of self-employment but also that openminded interest in various (industry) fields may be connected to with entrepreneurial activity. Either way, two main implications can be derived from these results. First, those planning to become entrepreneurs should be open to diverse industry fields when gaining skills and experience. Second, individuals who foster entrepreneurial activity (e.g., universities, incubators, entrepreneurship consultants) should integrate various industry perspectives in their approaches. Offering or fostering mixed-industry internships for students is only one approach that universities could consider for relevant study programs.

Moreover, balanced industry experience proves to be more important than experience in different management areas. Interestingly, the analysis does not show a positive impact of balanced management experience on the probability of self-employment. Nevertheless, even though management experience is not correlated to being an entrepreneur, it may have a positive impact on the success of running the business.

While other studies focus on the overall level of ESE (Chen et al. 1998; Piperopoulos and Dimov 2015), our analysis underlines the importance of a balanced combination of its components. In our sample, we observe a higher probability of becoming self-employed when there are numerous equal measures within the components of ESE. Importantly, by adding balanced self-efficacy, we not only focused on skills that were actually present but also focused on individually perceived skills as well.

Since ESE is a combination of perceived abilities in a variety of fields that are relevant for founding a business, this finding again strengthens the meaning of being a jacqueline-of-all-trades and broadens the understanding of Lazear's theory by focusing on searching, planning, marshaling, implementing-people, and implementing-financial as the sub- components of ESE. These fields can be integrated in practical or teaching models supporting entrepreneurial intentions. Future research should examine whether and how entrepreneurial skills result from traditional human capital indicators (Stuetzer et al. 2013).

We additionally controlled for age as a factor influencing self-employment and found a positive impact. This is in line with former work that shows a positive correlation between age and self-employment at decreasing rates (Kautonen et al. 2014). On the one hand, this finding may be explained by a changing risk perception with age. Even though studies have not yielded consistent evidence, it can be argued that after adolescence risk aversion decreases with age (Cutler 1995; Hallahan et al. 2004; Wang and Hanna 1997). Assuming that risk tolerance influences entrepreneurship (Block et al. 2015; Caliendo et al. 2014; Karlsson and Warda 2014; Nieß and Biemann 2014; Verheul et al. 2015), this argument can explain the above result. However, research on risk aversion and entrepreneurship has revealed conflicting results (Miner and Raju 2004). Recent research that shows a link between risk aversion and the motivation to gain a balanced skill set is promising (Hsieh et al. forthcoming). Future research might investigate the relationship between risk perception, age, and balanced skill sets with regard to women's entrepreneurship in particular. Women are seen as risk averse, which makes fear of failure a central hindering factor for entrepreneurship (Wagner 2007). On the other hand, our findings on age support the jack-of-all-trades hypothesis in general since it takes time to gain balanced skills in different areas.

Our results also reveal that particularly balanced industry experience is decisive for solo entrepreneurs who cannot easily compensate for missing skills. Future research should include information on team composition (Steffens et al. 2012) to explain in detail whether a balanced set of skills is related to entrepreneurial persistence and success. In summary, the results support the jack-of-all-trades hypothesis for a database of women only, while most of the existing studies are based on mixed-gender data (and therefore mainly men since there are still fewer women entrepreneurs). Thus, our results reveal that there is no gender difference concerning this point, although women tend to make their professional choices based on other motives, such as self-fulfillment, carrying out 
family responsibilities, and making a social impact. Building on these underlying motivations (in addition to the maximization of lifetime income), we assume that those with a balanced set of skills choose a selfemployed position to fulfill these respective motives. Following this line of argumentation, we might derive implications about fostering routes to both selfemployment and employee positions: For example, women who are motivated by generating social impact can be advised to find entrepreneurial solutions if they have a more balanced set of skills, while those with expert skills might find greater fulfillment in an employed position with more clearly defined tasks. The argumentation is similar when family duties play a central role within job decisions. Women with a balanced set of skills might successfully leverage the flexibility of self-employment, whereas female experts might be better off choosing, for example, part-time employment. Future research on the Jacqueline-of-all-trades hypothesis should thus be broadened by specifically integrating these alternative underlying motives (including the maximization of lifetime income). This approach will likely generate insights into the interdependencies of these motives with job choice (entrepreneurial or otherwise) and varieties of skills. It would also be interesting to take into account whether the respective decision for or against entrepreneurial behavior leads to the successful fulfillment of goals related to the underlying motives, depending on different skill sets. Such research would also produce additional knowledge relevant for men, but it would be especially relevant for women assuming a broader variety of job motives.

Even though a balanced set of skills and experience increases the probability of becoming an entrepreneur for both men and women, vast gender differences in founding rates still exist (Xavier et al. 2013). Women in general tend to start a business less often than men. Thus, the question arises whether differences in the skill bases of men and women can explain the differences in founding rates. If so, it could be concluded that the population of women in general possess a narrower skill and experience base and that women tend to be experts. This would be surprising since women are often said to possess a "multitasking talent" and often need a broader variety of skills for managing work and family tasks at the same time. Following this line of argument, women might have even better conditions for becoming entrepreneurs. If this were the case, it would become even more important to foster women's entrepreneurial power. However, there is no evidence in this study as to whether the balance of skills and experiences significantly and positively impacts the success of entrepreneurs. Analyzing the connection between being a jack-of-all-trades and entrepreneurial success would further deepen the understanding of entrepreneurial personalities (Morris et al. 2006). In this context, although we did not find that balanced management experience impacts women graduates' self-employment, prior research highlights a link between managerial skills and entrepreneurial performance (Lerner and Almor 2002). Furthermore, our finding about the widely discussed family-work conflict (Kirkwood and Tootell 2008; Ufuk and Ozgen 2001; Winn 2004) deserves attention. Including it as a control variable, we did not find any effect of having children for our sample of women graduates. However, there is an ongoing debate that sees a conflict between being a mother and being an entrepreneur as well as performing well as an entrepreneur (Boden 1999; CollinsDodd et al. 2004; Noseleit 2014; Shelton 2006).

In contrast to having children, the existence of a life partner decreases the probability of being self-employed. This result should also be investigated in more detail. While women with self-employed husbands seem more likely to be self-employed themselves (Bruce 1999), life partners appear to be a hindering factor for self-employment that deserves broader investigation (McGowan et al. 2012). In the context of the jack-of-all-trades hypothesis, a knowledge spillover effect from the life partner might even be assumed to increase women's probability of becoming self-employed (Özcan 2011). Future research might explore the human and social capital of the life partners and examine whether a spillover effect broadens women entrepreneurs' skills as well.

We wish to acknowledge some general limitations of our investigation. First, this is a cross-sectional approach measuring balanced ESE only as a snapshot at the time of investigation. Examining potential changes over time would improve the explanatory power of the results. Second, since the data are crosssectional, unobserved heterogeneity and potential endogeneity issues cannot be taken into account. Thus, in line with most former work, this study does not make any claims of causality. Third, our study focuses on women graduates in Germany, a unique 
group that may not be generalizable to other populations. Future work might broaden the approach to other groups.

Future research should also combine aspects of diversity in human and social capital with personality characteristics that are widely researched as factors related to self-employment (Caliendo et al. 2014; Simoes et al. 2015; Zhao and Seibert 2006). Moreover, Lazear's theory should be linked with persistence in self-employment and entrepreneurial success. Both are traditionally linked with human capital and personality characteristics (Glaub et al. 2014; Patel 2014). We were unable to account for environmental factors, such as family-related institutions (Terjesen et al. 2016; Terjesen and Elam 2012). We have left that for future research.

Nevertheless, as we have shown, several implications can be derived from our work. When it comes to entrepreneurship education, our results suggest there is great benefit in collecting experiences in diverse fields. This should include the sub-components of ESE as well as practice-oriented experiences in diverse industries. This diversified approach appears far more fruitful than concentrating on (various) management skills. The results also indicate a need for promoting professional training as a combination of school-based theoretical education with company-based traineeships.

\section{Conclusion}

The objective of this study was to apply Lazear's theory to a representative sample of women graduates and to determine whether graduate women entrepreneurs are jacquelines-of-all-trades. We investigated whether Lazear's theory holds true under additional assumptions beyond the mere maximization of lifetime income. Hence, we question whether Lazear's jack-of-all-trades hypothesis holds true for graduate women. Our study suggests that graduate women are more likely to be self-employed if they have more balanced — that is, less specialized-knowledge. Our research indicates that graduate women entrepreneurs indeed show a balanced set of skills, including additional professional training, balanced industry experience, and balanced entrepreneurship-based selfefficacy. Accordingly, Lazear's theory remains valid for women and is therefore gender neutral. Our study also confirms that Lazear's approach can be extended to additional motives beyond purely economic ones.

We also highlight the specifics of solo women entrepreneurs, who tend to have balanced industry experience more often than women who are part of a team or who have employees. This finding is particularly important because in many cases being a solo entrepreneur is the starting point of an entrepreneurial career.

Acknowledgments Silke Tegtmeier's contribution to the paper is part of the project "Herself-Self-employment in the Professional Career of Women Graduates", granted by the Federal Ministry of Education and Research, Germany (2012/ 2013). Agnieszka Kurczewska's contribution to the paper is part of the project financed by Ministry of Science and Higher Education in Poland, Mobility Plus Grant, 1100/MOB/2013/0.

Open Access This article is distributed under the terms of the Creative Commons Attribution 4.0 International License (http:// creativecommons.org/licenses/by/4.0/), which permits unrestricted use, distribution, and reproduction in any medium, provided you give appropriate credit to the original author(s) and the source, provide a link to the Creative Commons license, and indicate if changes were made.

\section{References}

Acs, Z., Bardasi, E., Estrin, S., \& Svejnar, J. (2011). Introduction to special issue of small business economics on female entrepreneurship in developed and developing economies. Small Business Economics, 37(4), 393-396.

Ahl, H. (2006). Why research on women entrepreneurs needs new directions. Entrepreneurship Theory and Practice, 30(5), 595-621.

Åstebro, T., Chen, J., \& Thompson, P. (2012). Stars and misfits: A theory of occupational choice. Management Science, 57(11), 1999-2017.

Åstebro, T., \& Thompson, P. (2011). Entrepreneurs, jacks of all trades or hobos? Research Policy, 40(5), 637-649.

Audretsch, D. B., Kuratko, D. F., \& Link, A. N. (2015). Making sense of the elusive paradigm of entrepreneurship. Small Business Economics, 45(4), 703-712.

Backes-Gellner, U., \& Moog, P. (2013). The disposition to become an entrepreneur and the jacks-of-all-trades in social and human capital. The Journal of Socio-Economics, $47,55-72$.

Bandura, A. (1978). The self system in reciprocal determinism. American Psychologist: Journal of the American Psychological Association, 33(4), 344-358.

Baron, R. (2006). Opportunity recognition as pattern recognition: How entrepreneurs "connect the dots" to identify new business opportunities. Academy of Management Perspectives, 20(1), 104-119. 
Baron, R., \& Henry, R. A. (2010). How entrepreneurs acquire the capacity to excel: Insights from basic research on expert performance. Strategic Entrepreneurship Journal, 4(1), 49-65.

Bates, T. (1995). Self-employment entry across industry groups. Journal of Business Venturing, 10(2), 143-156.

Biehl, A. M., Gurley-Calvez, T., \& Hill, B. (2014). Self-employment of older Americans: Do recessions matter? Small Business Economics, 42(2), 297-309.

Bird, B. (1989). Entrepreneurial behaviour. Glenview, IL: Scott, Foresman.

Blanchflower, D. G. (2000). Self-employment in OECD countries. Labour Economics, 7(5), 471-505.

Blanchflower, D. G. (2004). Self-employment: More may not be better. Swedish Economic Policy Review, 11(2), 15-73.

Boden, R, Jr. (1999). Flexible working hours, family responsibilities and female self-employment. American Journal of Economics and Sociology, 58(1), 71-83.

Borooah, V.K., Collins, G., Hart, M. \& MacNabb, A. (1997). Women and self employment: An analysis of constraints and opportunities in Northern Ireland. In D. Deakins, P. Jennings, \& C. Mason (Eds.), Small Firms: Entrepreneurship in the Nineties (pp. 72-88), National Small Firm's Policy and Research Conferences. London: Paul Chapman Publishing.

Bruce, D. (1999). Do husbands matter? Married women entering self-employment. Small Business Economics, 13(4), 317-329.

Brush, C. (1992). Research on women business owners: Past trends, a new perspective and future directions. Entrepreneurship Theory and Practice, 16(4), 5-30.

Caliendo, M., Fossen, F., \& Kritikos, A. S. (2014). Personality characteristics and the decisions to become and stay selfemployed. Small Business Economics, 42(4), 787-814.

Carter, N. M., Gartner, W. B., Shaver, K. G., \& Gatewood, E. J. (2003). The career reasons of nascent entrepreneurs. Journal of Business Venturing, 18(1), 13-39.

Chen, C. C., Greene, P. G., \& Crick, A. (1998). Does entrepreneurial self-efficacy distinguish entrepreneurs from managers? Journal of Business Venturing, 13(4), 295-316.

Clain, S. (2000). Gender differences in full-time self-employment. Journal of Economics and Business, 52, 499-513.

Collins-Dodd, C., Gordon, I., \& Smart, C. (2004). Further evidence on the role of gender in financial performance. Journal of Small Business Management, 42(4), 395-417.

Cutler, N. E. (1995). Three myths of risk tolerance: What clients are not telling you. Journal of the American Society of CLU \& ChFC, 49(1), 33-37.

Davidsson, P. (2005). Researching entrepreneurship. New York: Springer.

Douglas, E. J., \& Shepherd, D. A. (2002). Self-employment as a career choice: Attitudes, entrepreneurial intentions and utility maximization. Entrepreneurship Theory and Practice, 26(3), 81-90.

European Commission (2016). Eurostat-Your key to European statistics, http://epp.eurostat.ec.europa.eu/portal/page/ portal/eurostat/home. Accessed 20 Feb 2016.

Fischer, E. M., Reuber, A. R., \& Dyke, L. S. (1993). A theoretical overview and extension of research on sex, gender, and entrepreneurship. Journal of Business Venturing, 8(2), 151-168.
Folta, T. B., Delmar, F., \& Wennberg, K. (2010). Hybrid entrepreneurship. Management Science, 56(2), 253-269.

Galloway, L., Kapasi, I., \& Sang, K. (2015). Entrepreneurship, leadership, and the value of feminist approaches to understanding them. Journal of Small Business Management, 53(3), 683-692.

Galunic, D. C., \& Rodan, S. (1998). Resource recombinations in the firm: Knowledge structures and the potential for Schumpeterian innovation. Strategic Management Journal, 19(12), 1193-1201.

Georgellis, Y., \& Wall, H. J. (2005). Gender differences in selfemployment. International Review of Applied Economics, 19(3), 321-342.

Glaub, M. E., Frese, M., Fischer, S., \& Hoppe, M. (2014). Business managers or owners leads to entrepreneurial success: A theory-based controlled field intervention for evidence-based management. Academy of Management Learning and Education, 13(3), 354-379.

Gupta, V. K., Turban, D., \& Bhawe, N. M. (2008). The effect of gender stereotype activation on entrepreneurial intentions. Journal of Applied Psychology, 93(5), 1053-1061.

Gupta, V. K., Turban, D., Wasti, S. A., \& Sikdar, A. (2009). The role of gender stereotypes in perceptions of entrepreneurs and intentions to become an entrepreneur. Entrepreneurship Theory and Practice, 33(2), 397-417.

Hallahan, T. A., Faff, R. W., \& McKenzie, M. D. (2004). An empirical investigation of personal financial risk tolerance. Financial Services Review, 13, 57-78.

Hartog, J., Van Praag, M., \& Van Der Sluis, J. (2010). If you are so smart, why aren't you an entrepreneur? Returns to cognitive and social ability: Entrepreneurs versus employees. Journal of Economics \& Management Strategy, 19(4), 947-989.

Heimann-Roppelt, A., \& Tegtmeier, S. (in press). Sequence analysis in entrepreneurship research: Business founders' life courses and early-stage firm survival. International Journal of Entrepreneurial Venturing.

Holmquist, C., \& Carter, S. (2009). The Diana project: Pioneering women studying pioneering women. Small Business Economics, 32(2), 121-128.

Hsieh, C., Parker, S. C., \& van Praag, C. M. (forthcoming). Risk, balanced skills and entrepreneurship. Small Business Economics. Available at SSRN: http://ssrn.com/abstract= 1966517 or doi:10.2139/ssrn. 1966517.

Jennings, J. E., \& Brush, C. G. (2013). Research on women entrepreneurs: Challenges to (and from) the broader entrepreneurship literature? The Academy of Management Annals, 7(1), 661-713.

Karlsson, C., \& Warda, P. (2014). Entrepreneurship and innovation networks. Small Business Economics, 43(2), 393-398.

Kautonen, T., Down, S., \& Minniti, M. (2014). Ageing and entrepreneurial preferences. Small Business Economics, 42(3), 579-594.

Kirkwood, J. (2009). Motivational factors in a push-pull theory of entrepreneurship. Gender in Management: An International Journal, 24(5), 346-364.

Kirkwood, J., \& Tootell, B. (2008). Is entrepreneurship the answer to achieving work-family balance? Journal of Management and Organization, 14(3), 285-302. 
Krueger, N. F. (2007). What lies beneath? The experiential essence of entrepreneurial thinking. Entrepreneurship Theory and Practice, 31(1), 123-138.

Lazear, E. P. (2002). Entrepreneurship, National Bureau of Economic Research Working Paper 9109, August.

Lazear, E. P. (2005). Entrepreneurship. Journal of Labor Economics, 23(4), 649-680.

Lechmann, D. S. J., \& Schnabel, C. (2014). Are the self-employed really jacks-of-all-trades? Testing the assumptions and implications of Lazear's theory of entrepreneurship with German data. Small Business Economics, 42(1), 59-76.

Lerner, M., \& Almor, T. (2002). Relationships among strategic capabilities and the performance of women-owned small ventures. Journal of Small Business Management, 40(2), 109-125.

Lippman, S. A., \& Rumelt, R. P. (1982). Uncertain imitability: An analysis of inter firm deficiency under competition. The Bell Journal of Economics, 13(Autumn), 418-438.

Lofstrom, M. (2013). Does self-employment increase the economic well-being of low-skilled workers?. Small Business Economics, 40(4), 933-952.

Marlow, S. (1997). Self-employed women-New opportunities, old challenges? Entrepreneurship and Regional Development, 9(3), 199-210.

McGee, J. E., Peterson, M., Mueller, S. L., \& Sequeira, J. M. (2009). Entrepreneurial self-efficacy: Refining the measure. Entrepreneurship Theory and Practice, 33(July), 965-988.

McGowan, P., Redeker, C. L., Cooper, S. Y., \& Greenan, K. (2012). Female entrepreneurship and the management of business and domestic roles: Motivations, expectations and realities. Entrepreneurship and Regional Development, 24(1-2), 53-72.

Miner, J. B., \& Raju, N. S. (2004). Risk propensity differences between managers and entrepreneurs and between low- and high-growth entrepreneurs: a reply in a more conservative vein. Journal of Applied Psychology, 89(1), 3-13.

Morris, M. H., Miyasaki, N. N., Watters, C. E., \& Coombes, S. M. (2006). The dilemma of growth: Understanding venture size choices of women entrepreneurs. Journal of Small Business Management, 44(2), 221-244.

Neck, H. M., \& Greene, P. G. (2011). Entrepreneurship education: Known worlds and new frontiers. Journal of Small Business Management, 49(1), 55-70.

Nieß, C., \& Biemann, T. (2014). The role of risk propensity in predicting self-employment. Journal of Applied Psychology, 99(5), 1000-1009.

Noseleit, F. (2014). Female self-employment and children. Small Business Economics, 43(3), 549-569.

Oberschachtsiek, D. (2012). The experience of the founder and self-employment duration: a comparative advantage approach. Small Business Economics, 39(1), 1-17.

Özcan, B. (2011). Only the lonely? The influence of the spouse on the transition to self-employment. Small Business Economics, 37(4), 465-492.

Parker, S. (2009). The economics of entrepreneurship. New York: Cambridge Press.

Patel, P. C. (2014). Sticking it out: Individual attributes and persistence in self-employment. Journal of Management, 40(7), 1932-1979.
Pinkwart, A. (2000). Entrepreneurship als Gegenstand wirtschaftswissenschaftlicher Ausbildung. In G. Buttler, H. Herrmann, W. Scheffler, \& K. I. Voigt (Eds.), Existenzgründung: Rahmenbedingungen und Strategien (pp. 181-209). Heidelberg: Physica.

Piperopoulos, P., \& Dimov, D. (2015). Burst bubbles or build steam? Entrepreneurship education, entrepreneurial selfefficacy, and entrepreneurial intentions. Journal of Small Business Management, 53(4), 970-985.

Reynolds, P., Bosma, N., Autio, E., Hunt, S., De Bono, N., Servais, I., et al. (2005). Global entrepreneurship monitor: Data collection design and implementation 1998-2003. Small Business Economics, 24(3), 205-231.

Scott, C. E. (1986). Why more women are becoming entrepreneurs. Journal of Small Business Management, 24(4), $37-44$.

Shaver, K. G., Gartner, W. B., Gatewood, E. J., Crosby, E., Bakalarova, K. (2001). Attributions about entrepreneurship: A framework and process for analyzing reasons for starting a business. University of Illinois at UrbanaChampaign's Academy for Entrepreneurial Leadership Historical Research Reference in Entrepreneurship.

Shelton, L. M. (2006). Female entrepreneurs, work-family conflict, and venture performance: New insights into the work-family interface. Journal of Small Business Management, 44(2), 285-297.

Silva, O. (2007). The jack-of-all-trades entrepreneur: Innate talent or acquired skill? Economics Letters, 97(2), $118-123$.

Simoes, N., Crespo, N., \& Moreira, S. B. (2015). Individual determinants of self-employment entry: What do we really know? Journal of Economic Surveys,. doi:10.1111/joes. 12111.

Steffens, P., Terjesen, S., \& Davidsson, P. (2012). Birds of a feather get lost together: new venture team composition and performance. Small Business Economics, 39(3), 727-743.

Sternberg, R., Bergmann, H., \& Lückgen, I. (2004). Global entrepreneurship monitor-Unternehmensgründungen im weltweiten Vergleich, Länderbericht Deutschland 2003. Köln: Global Entrepreneurship Research Association.

Sternberg, R., Vorderwülbecke, A., \& Brixy, U. (2013). Global entrepreneurship monitor-Unternehmensgründungen im weltweiten Vergleich, Länderbericht Deutschland 2012. Hannover/Nürnberg: Global Entrepreneurship Research Association.

Stevenson, L. (1986). Against all odds: The entrepreneurship of women. Journal of Small Business Management, 24(4), 30-36.

Stuetzer, M., Obschonka, M., Davidsson, P., \& Schmitt-Rodermund, E. (2013). Where do entrepreneurial skills come from? Applied Economics Letters, 20(12), 1183-1186.

Svaleryd, H. (2015). Self-employment and the local business cycle. Small Business Economics, 44(1), 55-70.

Tegtmeier, S., \& Kurczewska, A. (in press). Business entry and window of opportunity-Empirical results for women entrepreneurs with graduate degree. International Journal of Entrepreneurial Venturing.

Tegtmeier, S., \& Mitra, J. (2015a). Determinants and measurement of entrepreneurial self-efficacy among women entrepreneurs: empirical evidence from Germany. In R. 
Blackburn, U. Hytti, \& F. Welter (Eds.), Frontiers in European entrepreneurship research (pp. 87-110). Cheltenham: Elgar.

Tegtmeier, S., \& Mitra, J. (2015b). Gender perspectives on university education and entrepreneurship: A conceptual overview. International Journal of Gender and Entrepreneurship, 7(3), 254-271.

Terjesen, S., Bosma, N., \& Stam, E. (2015). Advancing public policy for high-growth, female, and social entrepreneurs. Public Administration Review,. doi:10.1111/puar.12472.

Terjesen, S., \& Elam, A. (2012). Women entrepreneurship: A force for growth. In A. Riddle (Ed.), International trade forum magazine. United Nations International Trade Centre.

Terjesen, S., Hessels, J., \& Li, D. (2016). Comparative international entrepreneurship research: A review and research agenda. Journal of Management, 42(1), 299-344.

Terjesen, S., \& Lloyd, A. (2015). The 2015 Female Entrepreneurship Index: Analyzing the conditions that foster high-potential female entrepreneurship in 77 countries. Washington: The Global Entrepreneurship and Development Institute.

Ucbasaran, D., Westhead, P., \& Wright, M. (2008). Opportunity identification and pursuit: Does an entrepreneur's human capital matter? Small Business Economics, 30(2), 153-173.

Ufuk, H., \& Ozgen, O. (2001). Interaction between the business and family lives of women entrepreneurs in Turkey. Journal of Business Ethics, 31(2), 95-106.

Verheul, I., Block, J., Burmeister-Lamp, K., Thurik, R., Tiemeier, H., \& Turturea, R. (2015). ADHD-like behavior and entrepreneurial intentions. Small Business Economics, $45(1), 85-101$.
Wagner, J. (2003). Testing Lazear's jack-of-all-trades view of entrepreneurship with German micro data. Applied Economics Letters, 10(11), 687-689.

Wagner, J. (2006). Are nascent entrepreneurs "Jacks-of-alltrades"? A test of Lazear's theory of entrepreneurship with German data. Applied Economics, 38(20), 2415-2419.

Wagner, J. (2007). What a difference a Y makes-female and male nascent entrepreneurs in Germany. Small Business Economics, 28(1), 1-21.

Wang, H., \& Hanna, S. (1997). Does risk tolerance decrease with age? Journal of Financial Counseling and Planning, 8(2), 27-32.

Wilson, F., Marlino, D., \& Kickul, J. (2004). Our entrepreneurial future: examining the diverse attitudes and motivations of teens across gender and ethnic identity. Journal of Developmental Entrepreneurship, 9(3), 177-197.

Winn, J. (2004). Entrepreneurship: Not an easy path to top management for women. Women in Management Review, 19(3), 143-153.

Wood, R., \& Bandura, A. (1989). Social cognitive theory of organizational management. The Academy of Management Review, 14(3), 361-384.

Xavier, S. R., Kelley, D., Kew, J., Herrington, M., \& Vorderwülbecke, A. (2013). Global Entrepreneurship Monitor 2012 Global Report. London: Global Entrepreneurship Research Association.

Zhao, H., \& Seibert, S. E. (2006). The big five personality dimensions and entrepreneurial status: A meta-analytical review. Journal of Applied Psychology, 91(2), 259-271. 